\title{
The effect of plant extracts fed before farrowing and during lactation on sow and piglet performance
}

\author{
B. Matysiak ${ }^{\#}$, E. Jacyno, M. Kawęcka, A. Kołodziej-Skalska \\ \& A. Pietruszka \\ Department of Pig Breeding, Animal Feeding and Food, Faculty of Biotechnology and Animal Science, West \\ Pomeranian University of Technology in Szczecin, Poland
}

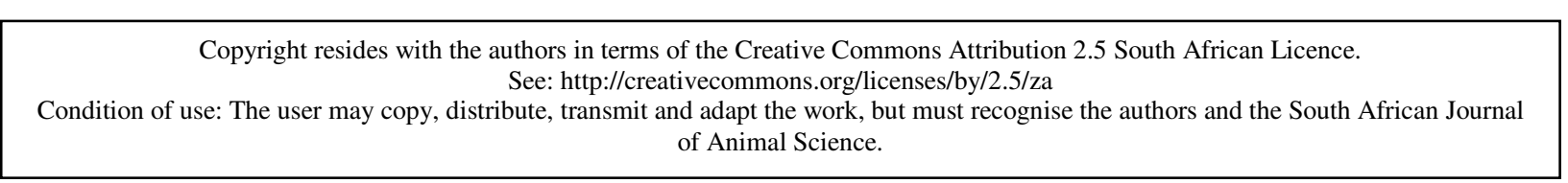

\begin{abstract}
The objective of this study was to investigate the effects of a mixture of plant extracts (XTRACT 6930), consisting of 5.4\% (wt/wt) carvacrol (oregano), 3.2\% cinnamaldehyde (cinnamon) and $2.2 \%$ capsicum oleoresin (Mexican pepper), on piglet and sow performance when used as dietary supplements to the sows. The experiment was performed on 40 sows, divided into two groups (control and experimental) of 20 sows per group. The study was conducted from day 90 of pregnancy until weaning at day 28 . The sows in the control group received the basal diet, and the sows in the experimental group (XT group) received the basal diet, supplemented with $100 \mathrm{mg}$ of XTRACT $/ \mathrm{kg}$ feed. Backfat thickness of the sows at points $\mathrm{P}_{2}$ and $\mathrm{P}_{4}$ was measured on day 90 of pregnancy and at weaning. Milk samples were collected from each sow on day $15 \pm 2$ of lactation. The backfat thickness of the sows that received the plant extracts was significantly thicker at weaning than that of the controls, showing less loss of backfat during lactation. The lactose content in the milk of the XTRACT group was higher than that of the control. Piglets of the sows supplemented with the plant extract had a significantly higher average daily gain during the suckling period and a higher body weight at weaning. The mortality of piglets during the suckling period was significantly lower in the XTRACT group than in the control group. The results showed that the plant extract supplementation of sows during late pregnancy and lactation had a beneficial effect on the performance of the sows and piglets.
\end{abstract}

Keywords: XTRACT 6930, carvacrol, cinnamaldehyde, capsicum oleoresin, sows, piglets

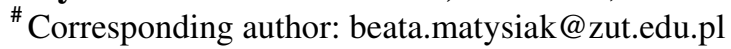

\section{Introduction}

Prohibition of the use of in-feed antibiotics in the European Union (EU) has increased interest in plant additives. A wide range of plants contain bioactive components (e.g. carvacrol, thymol, capsicum oleoresin, cinnamaldehyde, cineol, methyl eugenol, anethol, allicin, menthol) which have the potential to act as multifunctional animal supplements. The active components of oregano (carvacrol) and cinnamon (cinnamaldehyde) have antimicrobial properties (Didry et al., 1994; Dorman \& Deans, 2000). Roselli et al. (2007) found that allicin from garlic protects intestinal cells from the increased permeability of membranes in pigs infected with E. coli. Other studies showed that a mixture of cinnamon, thyme and oregano extracts inhibited the growth of coliform bacteria (Namkung et al., 2004). A combination of carvacrol, cinnamaldehyde and capsicum oleoresin had a beneficial effect on the gastrointestinal ecosystem and gastric emptying of weaned pigs (Manzanilla et al., 2004; Castillo et al., 2006). In addition, capsaicin, carvacrol and cinnamaldehyde are all potent antioxidants in vitro (Aeschbach et al., 1994; Dhuley, 1999; Kogure et al., 2002; Lee \& Shibamoto, 2002; Botsoglou, et al., 2004).

The growing, finishing pigs that were fed a diet with an oregano additive containing carvacrol and thymol experienced an improved daily gain and feed utilization, and reduced morality (Walter \& Bilkei, 2004). Weaner piglets receiving an oregano supplement had a higher weight gain and lower disease incidence compared with the unsupplemented control (Sads \& Bilkei, 2003). 
Plant extracts, therefore, may present an opportunity to enhance lactating sow and litter performance when used as dietary supplements. Added to the pre-farrowing and lactation diets of sows, oregano reduces the sow mortality rate and culling rate during lactation, and increases the farrowing rate and piglet health (Allan \& Bilkei, 2005). Khajarern and Khajarern (2002) reported an increased daily feed intake in lactating sows when oregano was added to their diet. In addition, daily weight gain was higher in pre-weaned pigs from those sows than in litters from sows not receiving oregano. The addition of a plant extract mixture containing carvacrol, cinnamaldehyde and capsicum to the lactation diets of sows improved nutrient digestibility and piglet performance prior to weaning (Ilsley et al., 2003).

In this study the effects were evaluated of a mixture of plant extracts containing carvacrol (oregano), cinnamaldehyde (cinnamon) and capsicum oleoresin (Mexican pepper), on the backfat thickness of sows during lactation, the milk composition of the sows, and piglet performance during suckling.

\section{Materials and Methods}

The study was carried out during the summer at a commercial farm on 200 sows (West Pomeranian Region, Poland, EU). Forty multiparous, hybrid sows (Polish Landrace x Polish Large White) were artificially inseminated with sperm from Pietrain x Duroc boars. On day 90 of pregnancy, 40 sows were assigned by the analogue method (body weight and parity) to two experimental groups of 20 pigs each, the

Table 1 Ingredient composition and nutritive value diets (as fed basis) ${ }^{1}$

\begin{tabular}{lc}
\hline Ingredient & Component $(\mathrm{g} / \mathrm{kg}$ feed $)$ \\
\hline Barley & 230.5 \\
Wheat & 300.0 \\
Naked oats & 150.0 \\
Maize & 100.0 \\
Wheat bran & 60.0 \\
Soybean meal (47\% CP) & 125.0 \\
Dicalcium phosphate & 2.5 \\
Premix $^{2}$ & 30.0 \\
Acidificator $^{3}$ & 2.0
\end{tabular}

Nutrients

Metabolizable energy, $\mathrm{MJ} / \mathrm{kg}^{4} \quad 13.2$

$\begin{array}{lr}\text { Crude protein, } \mathrm{g} / \mathrm{kg} & 179.0\end{array}$

Crude fibre, $\mathrm{g} / \mathrm{kg} \quad 39.6$

Lysine, $\mathrm{g} / \mathrm{kg} \quad 8.8$

Methionine + cystine, $\mathrm{g} / \mathrm{kg} \quad 6.1$

Threonine, $\mathrm{g} / \mathrm{kg} \quad 6.0$

Tryptophan, g/kg $\quad 1.9$

$\begin{array}{lr}\text { Calcium, } \mathrm{g} / \mathrm{kg} & 8.2\end{array}$

Phosphorus, $\mathrm{g} / \mathrm{kg} \quad 7.6$

\footnotetext{
${ }^{1}$ Experimental diet was supplemented with $100 \mathrm{mg}$ XTRACT 6930 per $\mathrm{kg}$ of feed.

${ }^{2}$ Provided the following per kg of diet: $90 \mathrm{mg} \mathrm{Mn} ; 99 \mathrm{mg} \mathrm{Zn;} 18 \mathrm{mg} \mathrm{Cu} ; 1.5 \mathrm{mg} \mathrm{I} ; 0.4 \mathrm{mg} \mathrm{Se} ; 120 \mathrm{mg} \mathrm{Fe}$;

$0.3 \mathrm{~g} \mathrm{Mg} ; 6.9 \mathrm{~g} \mathrm{Ca} ; 1.7 \mathrm{~g} \mathrm{P} ; 15000 \mathrm{IU}$ vitamin A; $1800 \mathrm{IU}$ vitamin $\mathrm{D}_{3} ; 60 \mathrm{mg}$ vitamin E; $2.25 \mathrm{mg}$ vitamin $\mathrm{K} ; 6$ $\mathrm{mg}$ vitamin $\mathrm{B}_{2} ; 2.4 \mathrm{mg}$ vitamin $\mathrm{B}_{6} ; 30 \mu \mathrm{g}$ vitamin $\mathrm{B}_{12} ; 60 \mathrm{mg}$ biotin; $1.5 \mathrm{mg}$ folic acid; $0.45 \mathrm{~g}$ choline chloride; $6 \mathrm{mg}$ pantothenic acid; $1.5 \mathrm{~g}$ lysine.

${ }^{3}$ Acidificator - lactic acid, formic acid.

${ }^{4}$ Calculated from Polish Norm of Pig Nutrition (1993).
} 
control and the supplemented group. The sows were housed in individual farrowing pens $(2.20 \times 1.80 \mathrm{~m})$. The farrowing pens had a partially slatted floor with a separate piglet creep area, maintained at a high temperature with a heat lamp. The piglets were suckled for 27 days and weaned on day 28 of lactation. From day 90 of pregnancy until weaning at day 28 , the sows in the control group were fed on the basal diet (Table 1 ), and the sows in the experimental group (XT group) on the basal diet supplemented with $100 \mathrm{mg}$ XTRACT $6930 / \mathrm{kg}$ (PANCOSMA co. Switzerland). The XTRACT consists of $5.4 \%$ (wt/wt) carvacrol (Origanum spp.), 3.2\% cinnamaldehyde (Cinnamomum spp.) and 2.2\% capsicum oleoresin (Capsicum annum).

From day 90 to 110 of pregnancy, the sows were fed $3.0 \mathrm{~kg} /$ day and from day 111 to farrowing, 2.0 $\mathrm{kg}$ /day. After farrowing, the sows were fed $1.5 \mathrm{~kg}$ of diet, which was increased to $2 \mathrm{~kg}$ at day 4 . From day 5 of lactation up to weaning, the diet was offered ad libitum (average $6.2 \mathrm{~kg} / \mathrm{head}$ ). Water was provided by nipple drinkers.

The piglets were offered a creep feed from day 10 of age until weaning. The creep feed of the piglets contained (per kg) $15.5 \mathrm{MJ}$ metabolizable energy, $210 \mathrm{~g}$ crude protein, $72 \mathrm{~g}$ crude fat, $25 \mathrm{~g}$ crude fibre, $13 \mathrm{~g}$ lysine, $4 \mathrm{~g}$ methionine. The basal diet contained $40 \%$ wheat, $30 \%$ barley, $20 \%$ soybean and $10 \%$ Suggi (mineral-vitamin mixture).

Backfat thickness at points $\mathrm{P}_{2}$ and $\mathrm{P}_{4}(3 \mathrm{~cm}$ and $8 \mathrm{~cm}$ respectively from the back midline behind the last rib) was measured on day 90 of pregnancy and at weaning. Backfat thickness was measured with an ultrasonic apparatus (Piglog 105; SFK-Technology, Denmark).

Approximately $15 \mathrm{~mL}$ of milk was collected from each sow on day $15 \pm 2$ of lactation to evaluate the composition of the milk. The milk samples were collected after an intramuscular injection of 20 IU of oxytocin and manual milking of the third and fourth anterior mammary glands on one side of the sow. Milk samples were frozen $\left(-20^{\circ} \mathrm{C}\right)$ immediately, pending analysis. The number of piglets born (total: number born alive and number stillborn) was recorded. Six hours after birth, the piglets were weighed separately and eartagged for individual identification. Individual piglets were weighed at day 21 and at weaning on day 28 of age. Piglet mortality from birth to weaning was recorded.

The chemical composition in the diet was determined by standard methods (AOAC, 1995), while amino acids in the diet were assayed with the Beckman automatic analyser. Phosphorus (P) was assayed by the vanadium-molybdenum photocolorimetric method, and calcium $(\mathrm{Ca})$ was checked by the emission spectrometry method on a Buck Scientific Spectrophotometer. The basic composition of the milk (dry matter, fat, protein and lactose) was determined by using an infrared milk analyser (Milko-Scan ${ }^{\mathrm{TM}}$ 133-B Analyser, Foss Electric, Hillerød, Denmark).

Conventional statistical methods were used to calculate means and standard error of the mean. To ascertain a significant difference between the levels of the main factor, the $t$-test was applied between means. For features which do not have a normal distribution, a nonparametric test U Mann-Whitney was applied. Statistical data analysis was undertaken using the STATISTICA PL Version 8.0 statistical package.

\section{Results}

Sows supplemented with the plant extract mixture had a higher backfat thickness at weaning (at points $\mathrm{P}_{2}-P<0.01 ; \mathrm{P}_{4}-P<0.05$ ) than the sows in the control (Table 2). The reduction in backfat thickness at $\mathrm{P}_{2}$ and $\mathrm{P}_{4}$ points from day 90 of pregnancy to weaning was lower $(P<0.01)$ in sows treated with the plant extract than the sows in the control.

Analysis of the sows' milk on day 15 of lactation indicated that the sows that received the added plant extract produced milk with a higher concentration of lactose $(P<0.01)$ than the control sows (Table 2). No differences were observed for milk protein, fat and dry matter levels between the two groups.

The total litter sizes (number of piglets born alive and stillborn) were similar in the two treatment groups (Table 3). However, the mortality of piglets from birth to weaning of the sows in the XT group was lower $(P<0.05)$ than that of the control group.

The body weight of the piglets and litters of the sows that were supplemented with the plant extracts was lighter at birth. However, during the 27 day suckling period they gained more body weight $(P<0.05)$ than those of the control sows (Table 4). Daily body weight gains from birth to weaning were also higher $(P$ $<0.05$ ) in piglets of sows that received the supplement than in piglets in the control. 
Table 2 Effect of including plant extract mixture (XT) in the diet of sows on their backfat thickness and milk composition

\begin{tabular}{|c|c|c|c|}
\hline \multirow{2}{*}{ Item } & \multicolumn{2}{|c|}{ Groups $^{1}$} & \multirow{2}{*}{ SEM } \\
\hline & Control & XT & \\
\hline No. of sows & 20 & 20 & \\
\hline \multicolumn{4}{|c|}{ Backfat thickness (mm) } \\
\hline \multicolumn{4}{|c|}{ d 90 of gestation } \\
\hline at P2 & 16.2 & 16.8 & 0.89 \\
\hline at $\mathrm{P} 4$ & 15.7 & 16.2 & 0.85 \\
\hline \multicolumn{4}{|l|}{ Weaning } \\
\hline at P2 & $13.7^{\mathrm{a}}$ & $15.6^{\mathrm{b}^{* *}}$ & 0.87 \\
\hline at $\mathrm{P} 4$ & 13.3 & $14.6^{*}$ & 0.85 \\
\hline \multicolumn{4}{|l|}{ Change } \\
\hline at P2 & $-2.4^{\mathrm{a}}$ & $-1.3^{\mathrm{b}^{* *}}$ & 0.36 \\
\hline at $\mathrm{P} 4$ & $-2.3^{\mathrm{a}}$ & $-1.6^{\mathrm{b}^{* *}}$ & 0.28 \\
\hline \multicolumn{4}{|c|}{ Milk composition (\%) } \\
\hline Dry matter & 16.19 & 16.21 & 0.43 \\
\hline Fat & 6.49 & 6.19 & 0.64 \\
\hline Protein & 4.20 & 4.14 & 0.31 \\
\hline Lactose & $5.00^{\mathrm{a}}$ & $5.82^{\mathrm{b}^{* *}}$ & 0.11 \\
\hline
\end{tabular}

Table 3 Effect of including plant extract mixture (XT) in the diet of sows on the average litter size of the sows at birth and weaning

\begin{tabular}{lccc}
\hline Item & \multicolumn{2}{c}{ Groups* } & \multirow{2}{*}{ SEM } \\
\hline No. of litters & 20 & 20 & \\
No. of piglets per litter: & & & \\
$\quad$ Total born & 11.7 & 11.8 & 0.42 \\
$\quad$ Born alive & 10.8 & 10.9 & 0.39 \\
$\quad$ Stillborn & 0.9 & 1.0 & 0.29 \\
$\quad$ Weaned & 9.9 & 10.4 & 0.42 \\
Mortality, birth to weaning (\%) & $8.6^{\text {a }}$ & $4.5^{\text {b }}$ & 1.95 \\
* Within rows, means with different superscripts are significantly different at $P<0.05$.
\end{tabular}

\section{Discussion}

In the current study, sows were supplemented with a mixture of plant extracts (containing carvacrol, cinnamaldehyde and capsicum oleoresin) from day 90 of pregnancy to weaning. This study showed that losses of backfat during lactation were lower in the plant extract-treated sows than in the control sows. This observation suggests lower mobilization results when plant extracts are used during lactation. On the other hand, Ilsley et al. (2003) found that dietary plant extracts (capsicum, carvacrol, cinnamaldehyde) had no significant effect on the loss of backfat during lactation in sows. 
Table 4 Effect of including plant extract mixture (XT) in the diet of sows on the weight of the piglets and litters and average daily gain of piglets

\begin{tabular}{|c|c|c|c|}
\hline \multirow{2}{*}{ Item } & \multicolumn{2}{|c|}{ Groups* } & \multirow{2}{*}{ SEM } \\
\hline & Control & XT & \\
\hline No. of litters & 20 & 20 & \\
\hline \multicolumn{4}{|l|}{ Litters weight $(\mathrm{kg})$} \\
\hline Birth & 15.3 & 14.7 & 0.41 \\
\hline Weaning & $65.7^{\mathrm{a}}$ & $76.0^{\mathrm{b}}$ & 1.12 \\
\hline \multicolumn{4}{|c|}{ Body weight of piglets $(\mathrm{kg})$} \\
\hline Birth & 1.42 & 1.36 & 0.09 \\
\hline Day 21 & 5.23 & 5.38 & 0.19 \\
\hline Weaning & $6.65^{\mathrm{a}}$ & $7.34^{\mathrm{b}}$ & 0.22 \\
\hline \multicolumn{4}{|c|}{ Average daily gain of piglets from birth $(\mathrm{g})$ : } \\
\hline to 21 days & 189 & 201 & 5.10 \\
\hline to weaning & $194^{\mathrm{a}}$ & $220^{\mathrm{b}}$ & 6.20 \\
\hline
\end{tabular}

The performance of sows during lactation, in particular milk production and composition, is critical to the survival of neonatal piglets and their growth prior to weaning. Therefore, factors that may enhance production and the composition of milk during lactation are critical for optimal litter weight gain. Our work and other studies (Miller, 2003) showed that a plant extract mixture containing carvacrol, cinnamaldehyde and capsicum oleoresin increased the concentration of lactose in sows' milk. Higher lactose content in milk can prevent hypoglycaemia and reduce piglet mortality.

In the study the inclusion of a combination of carvacrol, cinnamaldehyde and capsicum oleoresin in the sows' diet enhanced piglet performance and resulted in a higher average daily gain during the suckling period and a higher body weight at weaning. Similar results were shown in the study conducted by Ilsley et al. (2003). Other studies reported that oregano containing carvacrol enhances weight gain of piglets (Khajarern \& Khajarern, 2002; Sads \& Bilkei, 2003). The higher body gain of the piglets in our study suggests that sows treated with plant extracts produced more milk, perhaps as a consequence of improved intake and utilization of food. This had no relationship with sow backfat loss during lactation. Other authors showed that plant extracts containing capsicum, carvacrol and cinnamaldehyde had a beneficial effect on diet digestibility in the sows (Ilsley et al., 2003) and weaned piglets (Nualart et al., 2000). However, they had no effect on the appetite and food intake of the sows (Ilsley et al., 2003).

A study in cows showed that the metabolite, cinnamic aldehyde, was detected in milk, following dietary supplementation with cinnamon (Ando et al., 2001). There is also the possibility that active components of the plant extracts in the sow diet can be passed into the milk of the sow and have a beneficial effect on the performance of piglet.

In the current study, supplementing the diet of sows with plant extracts decreased the mortality of piglets during the suckling period. Other studies showed that oregano (Walter \& Bilkei, 2004; Allan \& Bilkei, 2005) and garlic and cinnamon extracts (Zigger, 2001) reduced the mortality of piglets. This could perhaps be as a consequence of a positive effect on the immune system and the antimicrobial effect of the plant extract (Azumi at al., 1997; Dorman \& Deans, 2000; Manzanilla at al., 2004; Kuhn et al., 2005).

\section{Conclusions}

The addition of a combination of carvacrol, cinnamaldehyde and capsicum oleoresin to the diet of sows before farrowing and during lactation decreased backfat loss during lactation in sows and increased milk lactose content in their milk. Supplementing the sows' diet with the plant extract, XTRACT 6930, had a beneficial effect on the growth rate and survival of their piglets during the suckling period. 


\section{References}

Aeschbach, K., Loliger, J., Scott, B.C., Murcia, A., Butler, J., Halliwell, B. \& Aruoma, O.I., 1994. Antioxidant actions of thymol, carvacrol, 6-gingerol, zingerone and hydroxytyrosol. Food Chem. Toxicol. 32, 31-36.

Allan, P. \& Bilkei, G., 2005. Oregano improves reproductive performance of sows. Theriogenology 63, 716-721.

Ando, S., Nishida, T., Ishida, I., Kochi, Y., Kami, A. \& Se, S., 2001. Transmission of herb essential oil to milk and change of milk flavour by feeding dried herbs to lactating Holstein Friesian cows. J. JPN Soc. Food Sci. 48, 142-145.

AOAC, 1995. Official Methods of Analysis (16th ed.). Association of Official Analytical Chemists, Inc., Arlington, Virginia, USA.

Azumi, S., Tanimura, A. \& Tanamoto, K., 1997. A novel inhibitor of bacterial endotoxin derived from cinnamon bark. Biochem. Biophys. Res. Commun. 234, 506-510.

Botsoglou, N.A., Christaki, E., Florou-Paneri, P., Giannenas, I., Papageorgiou, G. \& Spais, A.B., 2004. The effect of a mixture of herbal essential oils or $\alpha$-tocopheryl acetate on performance parameters and oxidation of body lipid in broilers. S. Afr. J. Anim. Sci. 34, 52-61.

Castillo, M., Martin-Orue, S.M., Roca, M., Manzanilla, E.G., Badiola, I., Perez, J.F. \& Gasa, J., 2006. The response of gastrointestinal microbiota to avilamycin, butyrate, and plant extracts in early-weaned pigs. J. Anim. Sci. 84, 2725-2734.

Dhuley, J.N., 1999. Antioxidant effects of cinnamon (Cinnamomum verum) bark and greater cardamom (Amomum sibulatum) seeds in rats fed high fat diet. Indian J. Exp. Biol. 37, 238-242.

Didry, N., Dubreuil, L. \& Pinkas, M., 1994. Activity of thymol, carvacrol, cinnamaldehyde and eugenol on oral bacteria. Pharm. Acta Helv. 69, 25-28.

Dorman, H.J. \& Deans, S.G., 2000. Antimicrobial agents from plants: Antibacterial activity of plant volatile oils. J. Appl. Microbiol. 8, 308-316.

Ilsley, S.E., Miller, H.M., Greathead, H.M.R. \& Kamel, C., 2003. Plant extracts as supplements for lactating sows: effects on piglet performance, sow food intake and diet digestibility. Anim. Sci. 77, 247-254.

Khajarern, J. \& Khajarern, S., 2002. The efficacy of origanum essential oils in sows feed. Int. Pig Topics 17, 17.

Kogure, K., Goto, S., Nishimura, M., Yasumoto, M., Abe, K., Ohiwa, C., Sassa, H., Kusumi, T. \& Terada, H., 2002. Mechanism of potent antiperoxidative effect of capsaicin. Biochim. Biophys. Acta 1573, 84-92.

Kuhn, G., Ender, K., Thomann, R., Tuchscherer, M., Tuchscherer, A., Stabenow, B., Krüger, M. \& Schrödl, W., 2005. Application of Echinacea - extract in pregnant and suckled sows. Arch. Tierz. 48, 270-282 [in German].

Lee, K.G. \& Shibamoto, T., 2002. Determination of antioxidant potential of volatile extracts isolated from various herbs and spices. J. Agric. Food Chem. 50, 4947-4952.

Manzanilla, E.G., Perez, J.F., Martin, M., Kamel, C., Baucells, F. \& Gasa, J., 2004. Effect of plant extracts and formic acid on the intestinal equilibrium of early-weaned pigs. Anim. Sci. 82, 3210-3218.

Miller, H.M., 2003. Effects of sow and piglet dietary supplementation with a plant extract additive on the composition of sow colostrums and milk (day 21) and its effects on piglet development from birth to day 6 postweaning. Final Year Project, Alex Moore 27/3/2003.

Namkung, H., Li, M., Gong, J., Yu, H., Cottrill, M. \& de Lange, C.F.M., 2004. Impact of feeding blends of organic acids and herbal extracts on growth performance, gut microbiota and digestive function in newly weaned pigs. Can. J. Anim. Sci. 84, 697-704.

Nualart, H., Kamel, C., Gasa, J. \& Baucells, F., 2000. Effects on faecal digestibility of the inclusion of a formulation of natural plant extracts on a post weaning pig diet from 5 to $15 \mathrm{~kg}$. Proc. EAAP. 2000, p. 43.

Polish Norm of Pig Nutrition, 1993. Institute of Animal Physiology and Nutrition. Omnitech Press, Warsaw. $1-87$.

Roselli, M., Britti, M.S., Le, Huërou-Luron, I., Marfaing, H., Zhu, W.Y. \& Mengheri, E., 2007. Effect of different plant extracts and natural substances (PENS) against membrane damage induced by enterotoxigenic Escherichia coli K88 in pig intestinal cells. Toxicol. in Vitro 21, 224-229. 
Sads, P.R. \& Bilkei, G., 2003. The effect of oregano and vaccination against Glasser's disease and pathogenic Escherichia coli on postweaning performance of pigs. Ir. Vet. J. 56, 611-615.

Walter, B.M. \& Bilkei, G., 2004. Immunostimulatory effect of dietary oregano etheric oils on lymphocytes from growth-retarded, low-weight growing-finishing pigs and productivity. Tijdschr. Diergeneesk. $129,178-181$.

Zigger, D., 2001. Healthier pigs on diet with garlic and cinnamon. Feed Technol. 5 (8/9), 17. 